\title{
What wars do with civilians
}

\begin{abstract}
This is a story of a refugee tortured by militia, in his home place country; he was a war injured patient. Thus, it makes him looking for a shelter for both him and all his family members. It was the worst experience as he said, looking forward to settle back in his country after the civil war.
\end{abstract}

Keywords: man, war, psychologist
Volume 4 Issue I - 2015

\author{
Sawsan Farhat \\ Psychologist, Jordan
}

Correspondence: Sawsan Farhat, Psychologist,Amman, Jordan, Email sawsanfarhatl8@yahoo.com

Received: March 07, 2015 | Published: October 16, 2015

\section{Opinion}

The patient is 36years old male, living with his wife and his two children in a caravan at a refugee camp. There he has his six brothers with their families living there as well. First and before I met him, his complaint was the pain he was suffering caused by the brutal way he had treated by militia. He's been shot right to his hip, what causes pelvic fraction and weakness in his right leg nerves. All of that prevented him from functioning in his daily basics activities. The patient was a computer engineer and his wife was a psychological councilor and now she is teaching children at the camp's primary school. I and a GP were a team, we passed to check on the patient and he had been examined by the GP who prescribed a tonic that might help with his weak nerves. As for me as a psychologist I centered on his reactions and body language .He was so much in deep pain. I tried to broke the ice and drift away his silence, by asking him few questions about his health while taking a detour to his psychological state. We chatted for about 10 minutes and I noticed tears in his eyes. I asked him if it relieves him to talk to a trustful person who can help him to insight his pain. He nodded and burst into tears.

I explained and assured him that all what he will say is so confidential between us and he can trust and rely on me to help him out of his sadness. At this point I noticed how eager he became to talk about the experience he had been through, for he clutched on his silence with either friends, relatives or anyone who contact with him. Now, seems it's time for me to find a key to his pain, so I started. 'I'm feeling all the pain inside you and I promise to provide help, support and trust whatever the issue is and never mind the time it takes. I'm here with you and for you and be sure the quality of your sayings will half the burden you are carrying. I'm all ears". The patient sighs and with eyes full of tears he started talking and he said: I had my degree in Information Technology when I was 21years old and I joined a grand IT company as a computer engineer. I lived in a classy level relying on the big salary I am getting. When the civil war started, I felt it's time for me to offer my obligation to my country and protect its interests from where my position is. Once and while I've been watching the news on TV, I noticed in the running news tape, distorted news about the war conditions and about rebellions. My mind was about to blow and I knew that a struggle is on the door. So, I decided to hack that news channel to change those information's the government distorted, it wasn't the meantime truth. But, my bad luck was that the intelligence agency was monitoring the source of the computer that output the information's and that's how they reached me.

I've been arrested after a too long chase and there was the time I've been shot right here to my hip and a bullet rested inside my hip bone causing pelvic fracture. I've been prisoned somewhere I don't know where for 30 days where I experienced a variety ways sanctioned by military individuals. It varied from punishments to a half fatal; there were severe physical and psychological abuse. Soon after I was prisoned, they ironically showed their skills in humiliating and destroying. I hardly bare to mention how they took off my clothes in front of other prisoners and pushed a thick stick topped with pins into my rectal area while joking and laughing out loud. All that suffering was pleasing them they were in ecstasy with joy. Sometimes they fill a container with water and charged it with high voltage and soaked his feet into it that explained the burns showed in both his feet. A month passed, but with daily brutal acts and humiliations.

Now, two hours session passed and I felt how tired the patient was. I asked if he would like to take a break and I will be back after tomorrow for the next session. But I was surprised that he asked if possible to be the next morning. I positively replied. Asking him to relax and assured him it would be our small secret. When I reached back to the clinic I was living with his story, it keeps my mind busy either in my way home and during the night and I could barely sleep. It wasn't only about the story I heard, but also I had a hunch and convinced there were more serious matters not yet mentioned. I set out to be his protecting angle, his supportive therapist and appointed his case.

There came the next day and I was there again with the patient. I asked him how he was doing! And he said he slept better than any time over the last 17 months. I was delighted to hear that and more. Happy for him. The second session started. I reminded the patient where we were stopped. So, he started telling me his story about the terrible events of that era of time. I heard more of the events listed in the first session, then I said:"ok, please go on with your story" He said: Why do you think I have more to say? I said: I thought you might have something more to share with me I'm your friend, aren't we friends now!!!, You do feel comfort with me !!And you trust me! Don't you? "He nodded. I had that strong feeling that there is something more serious and as if the patient noticed I'm pointing to a different type of sentences he buried deep down his long memory.

I asked him: can you tell me how your sexual life is!! I mean with your wife. Suddenly his tears overflowed as a waterfall. He said: "I've been released of prison, but it wasn't the end of suffering. A week later, the militia breaks through my home. Fortunately and for my good luck, is that my neighbor's sly out my children before any noticed they were there. Thanks God they are in good hands now. They are safe". Both I and my wife were there, both were unable to resist. We were cuffed in chairs for a while. Later they removed my cuffs, took all my clothes off and raped me alternately and repeatedly in front the sight of my wife, forcing her to watch. Sometimes they took my wife away of my sight to the other room .What are they doing to her inside there?? What if they are rapping her now?? I started to 
scream; someone came and punches me, so I fainted. A while later and when I was back to conscious, I asked about if my wife is ok!! One replied she is fine and safe inside. Too many questions popped to my mind; what if they are abusing her in any way? What if they are rapping her in front of each other?? Suddenly they all showed up naked with no shame, I was about to lose my mind". On day six they left away he said, but they also left wounds, soars, scars not only on my body, but also heart and brain wounds.

Few days and one of his relatives came by to lift them to the boarders and then to the nearby country to a refugee camp. He went on saying: "The problem now is that since our arrival to this moment I never came near my wife (meaning never had a sexual relationship with her) for more than a reason. The first I am feeling ashamed of what the militia did to me in front of my wife, Second I'm feeling guilty of all what my wife been through. Third I can't get to near her assuming that she had been raped and that's agitating me." That session took more than two hours to assure him that everything will go to be fine. And It was my turn to explain and analyze things for him to give him power and strength to face his problem then to get him out of fear, shame and suspicious. He asked for another session the next day and that's what has had done. He was so pleased and the first time I saw him smiling. He's been feeling more relaxed. He said he slept all night long and he talked with his wife and spent more time together, but no sexual act. It was fine with me at that time as long as he is improving medically and psychologically. After two weeks I found a job for him inside the camp and things went much better. I followed him up once in a week for a psychotherapy session and after a month passed he got back to his normal life with his wife. Things gradually improving. I am so happy.

\section{Acknowledgments}

None.

\section{Conflicts of interest}

Author declares there are no conflicts of interest.

\section{Funding}

None. 